\title{
Conventional Cardiac Rhabdomyoma
}

National Cancer Institute

\section{Source}

National Cancer Institute. Conventional Cardiac Rhabdomyoma. NCI Thesaurus. Code C49179.

A cardiac rhabdomyoma characterized by the presence of neoplastic large striated muscle cells with clear cytoplasm and spider cells. 